\title{
Effects of Chronic Exposures to Ozone on the Growth of Sunflower Plants
}

\author{
Hideyuki Shimizu*, Satoru Motohashi**, Hideo Iwaki**, \\ Akio FurukawA* and Tsumugu TotsukA* \\ *Division of Environmental Biology, the National Institute for Environmental Studies, \\ Tsukubagakuen, Ibaraki 305, Japan \\ **Institute of Biological Science, the University of Tsukuba, \\ Sakura-mura, Ibaraki 305, Japan
}

(Received September 4, 1981)

\begin{abstract}
Fourteen-day-old sunflower plants (Helianthus annuus L. cv. Russian Mammoth) were exposed to 0.1 or $0.2 \mathrm{ppm}$ ozone $\left(\mathrm{O}_{3}\right)$ for 12 days in an artificially-lighted growth cabinet. Plants were harvested 0,6 and 12 days after the start of exposure, and the growth analysis was performed. White fleck of injury developed on many leaves after the exposure to 0.1 or $0.2 \mathrm{ppm}_{3}$ for 1-2 days, and subsequently withering of old leaves was accelerated. Twelve days after the start of exposure, the dry weight of whole plant was reduced by $11 \%$ and $32 \%$ of the control by 0.1 and $0.2 \mathrm{ppm}_{3}$, respectively. Root growth was markedly inhibited by $\mathrm{O}_{3}$, while leaf growth was slightly inhibited. Relative growth rate (RGR) and net assimilation rate (NAR) were reduced by $0.1 \mathrm{ppm} \mathrm{O}_{3}$ for the first 6 days, but were not affected for the following 6 days. The RGR and the NAR were reduced by $0.2 \mathrm{ppm}$ $\mathrm{O}_{3}$ throughout the exposure period. For the last 6 days, the RGR was less affected by $0.2 \mathrm{ppm} \mathrm{O}_{3}$ than the NAR, owing to the increase in leaf area ratio (LAR). Leaf weight ratio (LWR) was also increased by $\mathrm{O}_{3}$ exposure, whereas stem weight ratio (SWR) and root weight ratio (RWR) were reduced. These changes in growth parameters suggest that the chronic exposures to low concentrations of $\mathrm{O}_{3}$ should affect the net photosynthesis and the partitioning ratio of photosynthates in sunflower plants.
\end{abstract}

\section{INTRODUCTION}

Photochemical oxidants are the most important and widespread types of air pollutants in recent years. Injurious effects of the oxidants on agricultural and native vegetations have been investigated by many workers (see reviews $\left.{ }^{1-4}\right)$. Ozone $\left(\mathrm{O}_{3}\right)$, which is a major component of photochemical oxidants, is probably more injurious to plants than any other air pollutants. ${ }^{5,6)}$ Acute injuries induced by $\mathrm{O}_{3}$ have been studied extensively. High concentrations of $\mathrm{O}_{3}$ usually cause the visible symptoms of injury on leaves ${ }^{6-9)}$ and affect the rates of photosynthesis, respiration and transpiration within a few hours. ${ }^{10-15)}$

Chronic effects on plants of long-term exposures to relatively low concentrations of $\mathrm{O}_{3}$ are considered to be more practical and important subjects at present. There has been an increasing number of studies concerning the chronic effects of $\mathrm{O}_{3}$ on growth and yield of many plants. FEDER ${ }^{16)}$ reported that the low concentrations of $\mathrm{O}_{3}$ inhibited the flower formation of carnation and geranium plants. HEAGLE et al. ${ }^{17)}$ documented that the exposure to $0.1 \mathrm{ppm}_{3}$ for 67 days significantly reduced the 
yield of a hybrid sweet corn. The results from Tingey et al. ${ }^{18)}$ showed that 3-week exposure to $0.1 \mathrm{ppm} \mathrm{O}_{3}$ could reduce the growth of soybean plants. Similar reduction in growth and/or yield have been also reported on many other plant species. ${ }^{19-24)}$ However, HARWARD and TRESHOW, ${ }^{25)}$ reported that some understorey plants in the aspen zone significantly increased in the dry weight growth and the seed production by the exposure to 0.06 or $0.15 \mathrm{ppm} \mathrm{O}_{3}$. From many other investigations, BENNETT et al. ${ }^{26)}$ compiled evidences indicating the increase in growth of plants exposed to low concentrations of $\mathrm{O}_{3}$, and showed in their own experiments that 12-day exposure to $0.03 \mathrm{ppm}_{3}$ stimulated the growth of bean, barley and smart weed.

These conflicting results indicate that the chronic effects of low concentrations of $\mathrm{O}_{3}$ on plant growth have not been clarified. Furthermore, almost all of these experiments were conducted to determine the effects of $\mathrm{O}_{3}$ only by a single harvest procedure. The changes in growth and yield should be the results of many physiological and biochemical changes. In order to examine the chronic effects of $\mathrm{O}_{3}$ on plant growth precisely, the effects on several growth parameters should be investigated.

In the present study, we exposed sunflower plants to 0.1 and $0.2 \mathrm{ppm} \mathrm{O}_{3}$ continuously for 12 days, and detected the effects of $\mathrm{O}_{3}$ on several growth parameters by means of the plant growth analysis. This procedure might provide the information concerning the physiological changes in $\mathrm{O}_{3}$-exposed plants. Furthermore, we tried to give an explanation of the conflicting results reported by other workers.

\section{MATERIALS AND METHODS}

Plant material. Sunflower seeds which were obtained from the plants bred in our institute were dipped into water for $12 \mathrm{hr}$ and then sterilized by dipping into $\lg l^{-1}$ Benlate solution (Dupont, Delaware, U.S.A.) for 30 minutes, followed by rinsing with running tap water for $2 \mathrm{hr}$. Three seeds were directly sown in each plastic pot $(11 \mathrm{~cm}$ in diameter and $20 \mathrm{~cm}$ high) containing a mixture of vermiculite, peat moss, perlite and fine gravel $(4: 4: 2: 1, \mathrm{v} / \mathrm{v})$. As basal fertilizers, $5 \mathrm{~g}$ of Magamp $\mathrm{K}$ $\left(\mathrm{N}: \mathrm{P}_{2} \mathrm{O}_{5}: \mathrm{K}_{2} \mathrm{O}=6: 40: 5\right.$, W. R. Grace Co., Tennessee, U.S.A.) was added to each pot, and the medium was adjusted to $\mathrm{pH} 6.4$ with magnesia lime (about $15 \mathrm{~g} \mathrm{pot}^{-1}$ ). Plants were fertilized regularly (1-3 times week ${ }^{-1}$ ) with $100-200 \mathrm{ml}$ of $0.1 \%$ Hyponex solution $\left(\mathrm{N}: \mathrm{P}_{2} \mathrm{O}_{5}: \mathrm{K}_{2} \mathrm{O}=6.5: 6: 19\right)$ plus Hoagland's No. 2 micro nutrients ${ }^{27}$ ) and watered regularly or daily as needed.

After sowing the pots were brought into a controlled environment growth cabinet $\left(170 \times 230 \times 190 \mathrm{~cm}^{3}\right.$, Koito Co. Ltd. $)$ to grow plants under the following environmental conditions. Air temperature in the cabinet was $25 \pm 0.5^{\circ} \mathrm{C}$, and relative humidity was $75 \pm 5 \%$. Light source consisted of twenty-four $400 \mathrm{~W}$ stannous halide lamps (Yoko Lamp, Toshiba), and long wavelength $(>800 \mathrm{~nm})$ of the emitted radiation was eliminated through a heat absorbing glass filter. Light intensity was about $420 \mu \mathrm{E}$ $\mathrm{m}^{-2} \mathrm{sec}^{-1}$ (ca. $115 \mathrm{~W} \mathrm{~m}^{-2}, 30 \mathrm{klux}$ ) at plant height. Light/dark cycle was $14 / 10 \mathrm{hr}$. Fresh air was led into the cabinet after being passed through activated charcoal and catalist-bearing (containing $\mathrm{MnOx}$ and $\mathrm{CuO}$ ) filters to remove ambient air pollutants. Air velocity in the cabinet was $0.2-0.4 \mathrm{~m} \mathrm{sec}^{-1}$, and ventilation rate was $75 \mathrm{~m}^{3} \mathrm{hr}^{-1}$ (ca. 10 times $\left.\mathrm{hr}^{-1}\right)$. The concentration of carbon dioxide $\left(\mathrm{CO}_{2}\right)$ in the cabinet was continuously monitored and regulated at $400 \pm 4 \mathrm{ppm}$ throughout the experimental period with a controlling system equipped with a infrared $\mathrm{CO}_{2}$ gas analyzer (URA-2S, Shimadzu). In the growth cabinet, plants were rotated on a turntable to minimize 
possible position effects.

Seedlings were selected for uniformity and thinned to a single plant per pot 7 days after sowing. Twelve-day-old plants were transferred to another controlled environment growth cabinet for $\mathrm{O}_{3}$ exposure (Koito Co. Ltd.). The size and the environmental conditions in this cabinet were the same as those in the cabinet where plants had been grown previously, except for the high ventilation rate up to $800 \mathrm{~m}^{3} \mathrm{hr}^{-1}$ (ca. 110 times $\mathrm{hr}^{-1}$ ) to minimize the effects of unknown pollutants which might be produced by photochemical reactions in the cabinet.

Exposure to $\mathrm{O}_{3}$. Fourteen-day-old plants were exposed to $\mathrm{O}_{3}$ for 12 days. $\mathrm{O}_{3}$ was generated by a silent electrical discharge in dry oxygen and mixed with the filtrated fresh air, and the mixture was led into the cabinet. The concentration of $\mathrm{O}_{3}$ in the cabinet was monitored continuously and regulated by a controlling system based on a chemiluminescent $\mathrm{O}_{3}$ analyzer (Model 806, Kimoto). Growth experiments consisted of three separate experiments. The concentration of $\mathrm{O}_{3}$ in each experiment was $0.0 \mathrm{ppm}$ (control), $0.1 \pm 0.002 \mathrm{ppm}$ or $0.2 \pm 0.004 \mathrm{ppm}$. Environmental conditions inside the cabinet were almost identical among the three experiments except for the $\mathrm{O}_{3}$ concentration and were kept constant during the growth experiments.

Harvests and growth analysis. Plants were harvested just before the start of $\mathrm{O}_{3}$ exposure ( 0 day) and also harvested 6 and 12 days thereafter. The extents of visible injury and withering in each leaf were visually assessed in $5 \%$ increments of leaf area. Area of each leaf was measured by an automatic planimeter (Model 3100, LI-COR Co.Ltd.). Total number of leaves and plant height were recorded. Then plants were divided into leaf laminae, stem, root, flower bud and withered leaves, which were dried at $80-90^{\circ} \mathrm{C}$ for $3-5$ days and then weighed. Stem part included leaf petioles.

Relative growth rate (RGR), net assimilation rate (NAR), leaf area ratio (LAR), specific leaf area (SLA), leaf weight ratio (LWR), stem weight ratio (SWR) and root weight ratio (RWR) were calculated according to the following formulae: ${ }^{28)}$

$$
\begin{aligned}
\mathrm{RGR} & =\frac{1}{W} \cdot \frac{d W}{d t}=\frac{\ln W_{2}-\ln W_{1}}{t_{2}-t_{1}} \\
\mathrm{NAR} & =\frac{1}{\bar{F}} \cdot \frac{d W}{d t}=\frac{\left(W_{2}-W_{1}\right) \cdot\left(\ln \bar{F}_{2}-\ln \bar{F}_{1}\right)}{\left(t_{2}-t_{1}\right) \cdot\left(\bar{F}_{2}-\bar{F}_{1}\right)} \\
\mathrm{LAR} & =\bar{F} / W \\
\mathrm{SLA} & =\bar{F} / F \\
\mathrm{LWR} & =F / W \\
\mathrm{SWR} & =S / W \\
\text { and } \quad \mathrm{RWR} & =R / W
\end{aligned}
$$

where $W_{i}$ and $\bar{F}_{i}$ are the dry weight of whole plant and the leaf area at time $t_{i}(i: 1$ and 2), respectively. $F, S$ and $R$ are the dry weight of leaves, stem and root, respectively.

\section{RESULTS}

\section{Visible injury caused by $\mathrm{O}_{3}$ exposure}

The symptom of visible injury was first noted as white fleck ${ }^{4,6)}$ within 2 days after the start of exposure to 0.1 or $0.2 \mathrm{ppm} \mathrm{O}_{3}$, and was most notable on the tip or the edge of upper surface of leaf laminae, especially of matured leaves. As the ex- 
Table 1 Effects of $\mathrm{O}_{3}$ exposure on some characteristics of sunflower plants. ${ }^{\text {a }}$

\begin{tabular}{lccc}
\hline & \multicolumn{3}{c}{$\mathrm{O}_{3}$ concentration (ppm) } \\
\cline { 2 - 4 } & 0.0 (control) & 0.1 & 0.2 \\
\hline Visible injury (\%)b) & $1.2 \pm 0.4$ & $9.5 \pm 5.2^{* * * d}$ ) & $46.8 \pm 7.3^{* * *}$ \\
Withering $(\%)^{\mathrm{b}}$ ) & $1.1 \pm 0.4$ & $3.4 \pm 0.5^{* * *}$ & $12.0 \pm 2.6^{* * *}$ \\
Withered leaves (mg dry wt) & $68.2 \pm 23.8$ & $206.5 \pm 38.2^{* * *}$ & $695.2 \pm 139.7^{* * *}$ \\
Flower bud (mg dry wt) & $17.3 \pm 6.9$ & $16.0 \pm 5.8$ & $10.6 \pm 3.8^{* *}$ \\
Number of leaves & $24.4 \pm 1.2$ & $23.7 \pm 1.8$ & $26.6 \pm 2.2^{* *}$ \\
Plant height (cm) & $48.2 \pm 3.4$ & $47.1 \pm 3.0$ & $42.8 \pm 3.8^{* *}$ \\
\hline
\end{tabular}

a) Plants were harvested 12 days after exposure started. Mean of 12 plants and standard deviation are indicated for each sample.

b) Percentage of the total leaf dry weight.

c) Including the yellow coloring and withering of leaves.

d) Significance of difference from control (t-test), ${ }^{* *} P<0.01, * * * P<0.001$.

posure continued, the symptom spread on the expanded leaves and appeared even on the upper young leaves. Furthermore, $\mathrm{O}_{3}$ exposure accelerated the withering of lower old leaves, which was apparently similar to that of naturally senescent leaves. With increase in concentration of $\mathrm{O}_{3}$, the degrees of visible injury and of withering of leaves increased. Effects of $\mathrm{O}_{3}$ exposure on these characteristics were summarized in Table 1.

\section{Effects of $\mathrm{O}_{3}$ on dry matter production}

As shown in Fig. 1, dry weight growth of whole plant was significantly reduced $(P<0.001)$ by the exposure to 0.1 or $0.2 \mathrm{ppm} \mathrm{O}_{3}$ for 6 days. At the final harvest, the dry weight of plants exposed to 0.1 and $0.2 \mathrm{ppm}_{3}$ was smaller by $11 \%$ and $32 \%$

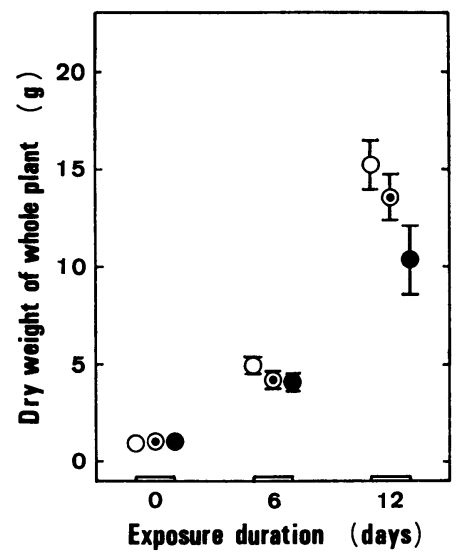

Fig. 1 Effect of $\mathrm{O}_{3}$ exposure on the increase in dry weight of whole plant. Dry weight of withered leaves was excluded. $\mathrm{O}_{3}$ exposure was started 14 days after sowing and continued for 12 days thereafter. Each symbol is the mean of 12 plants and vertical bars indicate \pm standard deviation of the mean.

$\bigcirc: 0 \mathrm{ppm}$ (control), $\bigcirc: 0.1 \mathrm{ppm}, \bullet: 0.2 \mathrm{ppm} \mathrm{O}_{3}$ exposure treatment. 


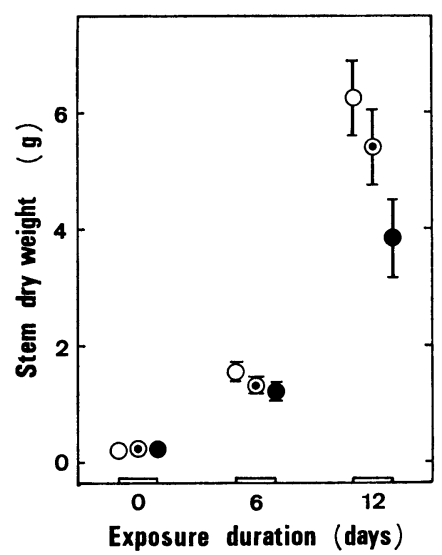

Fig. 2 Effect of $\mathrm{O}_{3}$ exposure on the increase in dry weight of stem. Symbols and conditions are the same as in Fig. 1.

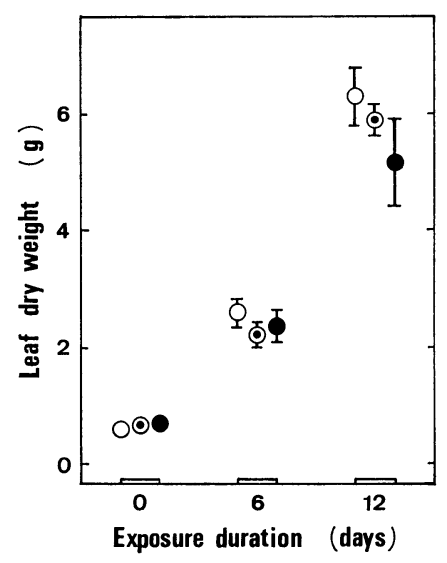

Fig. 4 Effect of $\mathrm{O}_{3}$ exposure on the increase in dry weight of leaves. Symbols and conditions are the same as in Fig. 1.

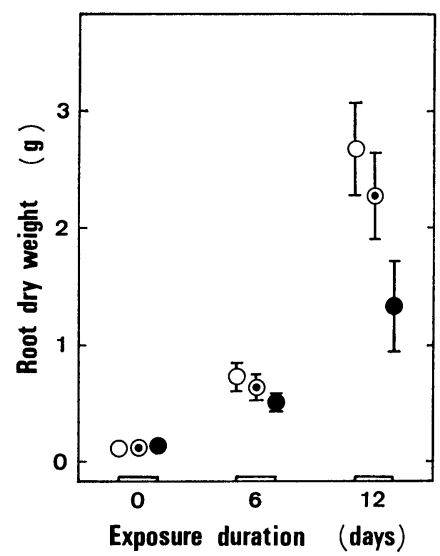

Fig. 3 Effect of $\mathrm{O}_{3}$ exposure on the increase in dry weight of root. Symbols and conditions are the same as in Fig. 1.

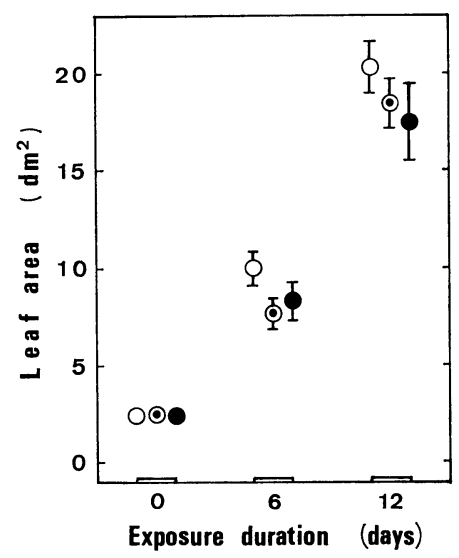

Fig. 5 Effect of $\mathrm{O}_{3}$ exposure on the increase in leaf area. Symbols and conditions are the same as in Fig. 1.

than that of control plants, respectively.

The effects of $\mathrm{O}_{3}$ on dry weight growth of stem, root and leaf laminae are shown in Figs. 2, 3 and 4, respectively. Six-day exposure to 0.1 or $0.2 \mathrm{ppm}_{3}$ was sufficient to reduce the dry weight growth of each organ. Compared with the control plants, the stem dry weight at the final harvest revealed $13 \%$ and $38 \%$ reductions for plants exposed to 0.1 and $0.2 \mathrm{ppm} \mathrm{O}_{3}$, respectively. Drastic reduction in the dry weight growth of root was caused by $\mathrm{O}_{3}$ exposure. At the final harvest, the root dry weight of $0.1 \mathrm{ppm} \mathrm{O}_{3}$-exposed plants was smaller by $15 \%$ than that of contorl plants, while a $50 \%$ reduction was caused by $0.2 \mathrm{ppm} \mathrm{O}_{3}$. Leaf growth was also reduced by $\mathrm{O}_{3}$ ex- 
Table 2 Effects of $\mathrm{O}_{3}$ exposure on the relative growth rate (RGR) and the net assimilation rate (NAR) of sunflower plants. ${ }^{a}$ )

\begin{tabular}{|c|c|c|c|c|}
\hline & \multirow{2}{*}{$\begin{array}{c}\text { Exposure } \\
\text { duration } \\
\text { (days) }\end{array}$} & \multicolumn{3}{|c|}{$\mathrm{O}_{3}$ concentration $(\mathrm{ppm})$} \\
\hline & & 0.0 (control) & 0.1 & 0.2 \\
\hline RGR & $0-6$ & 0.276 & 0.235 & 0.224 \\
\hline$\left(m g g^{-1}\right.$ day $\left.^{-1}\right)$ & $6-12$ & 0.189 & 0.196 & 0.154 \\
\hline NAR & $0-6$ & 1.232 & 1.149 & 1.058 \\
\hline$\left(\mathrm{mg} \mathrm{cm}^{-2} \mathrm{day}^{-1}\right)$ & $6-12$ & 1.185 & 1.274 & 0.844 \\
\hline
\end{tabular}

a) Dry weight of withered leaves was excluded to calculate these values.

posure. Although the withering of lower leaves was accelerated, the growth reduction of leaf dry weight caused by $\mathrm{O}_{3}$ exposure was less than that of stem or root. The exposure to $0.2 \mathrm{ppm}_{3}$ reduced leaf dry weight by $18 \%$, and $0.1 \mathrm{ppm} \mathrm{O}_{3}$ reduced by only $6 \%(P<0.05)$ even when the exposure was continued for 12 days. A slight reduction in leaf area growth was also detected in the $\mathrm{O}_{3}$-exposed plants (Fig. 5). At the final harvest, the leaf area of plants exposed to 0.1 and $0.2 \mathrm{ppm} \mathrm{O}_{3}$ was smaller by $9 \%$ and $14 \%$ than that of control plants, respectively.

The exposure to $\mathrm{O}_{3}$ did not influence the number of leaves emerged, irrespective of the withering of old leaves, except that 12-day exposure to $0.2 \mathrm{ppm} \mathrm{O}_{3}$ stimulated the development of new leaves (Table 1). Flower bud was observed on the top

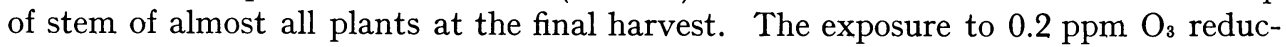
ed the dry weight of flower bud by $39 \%$ of the control value, though $0.1 \mathrm{ppm} \mathrm{O}_{3}$ had no significant effect (Table 1). Stem elongation expressed as plant height was depressed by $\mathrm{O}_{3}$ exposure (Table 1), but the suppression was not so remarkable as the reduction in dry weight growth of stem.

\section{Effects of $\mathrm{O}_{3}$ on growth parameters}

The data presented in the previous section (Figs. 1-5) were subjected to the growth analysis. Table 2 shows the changes in RGR and NAR of plants in each treatment. For the first 6 days of exposure, the RGR of sunflower plants was reduced in 0.1 and $0.2 \mathrm{ppm} \mathrm{O}_{3}$ by $15 \%$ and $19 \%$ of that of the control, respectively. For the following 6 days, the exposure to $0.2 \mathrm{ppm} \mathrm{O}_{3}$ resulted in the same extent of reduction in RGR as before, whereas $0.1 \mathrm{ppm} \mathrm{O}$ caused a slight increase. The change in NAR caused by $\mathrm{O}_{3}$ resembled with the change in RGR. The NAR of plants exposed to $0.1 \mathrm{ppm} \mathrm{O}_{3}$ was smaller than that of the control plants for the first 6 days but somewhat larger for the following 6 days. The exposure to $0.2 \mathrm{ppm} \mathrm{O}_{3}$ reduced the NAR during the exposure period for 12 days. By the way, the reduction in NAR amounted to $29 \%$ of the control value and was larger than that in RGR for the last 6 days.

As RGR is the product of NAR and LAR, effect of $\mathrm{O}_{3}$ on LAR should be investigated (Fig. 6). The exposure to $0.2 \mathrm{ppm} \mathrm{O}_{3}$ increased the LAR by $28 \%$ of the control value at the final harvest. LAR was further divided into SLA and LWR. The SLA was only slightly increased by $\mathrm{O}_{3}$ exposure (data not shown), whereas the LWR of plants pronouncedly increased with prolonged duration of exposure and with increased concentration of $\mathrm{O}_{3}$ (Fig. 7): At the final harvest, the exposure to $0.2 \mathrm{ppm}$ 


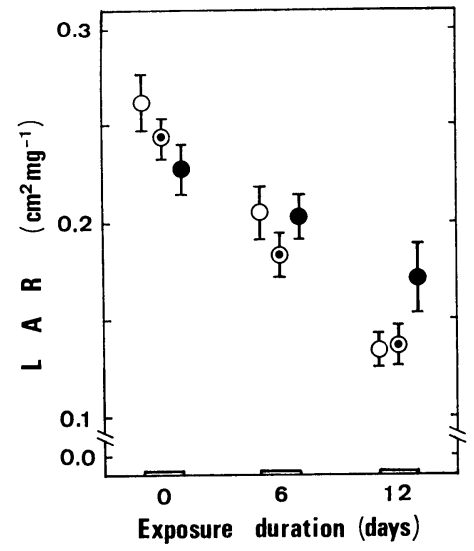

Fig. 6 Effect of $\mathrm{O}_{3}$ exposure on the leaf area ratio (LAR). Symbols and conditions are the same as in Fig. 1.

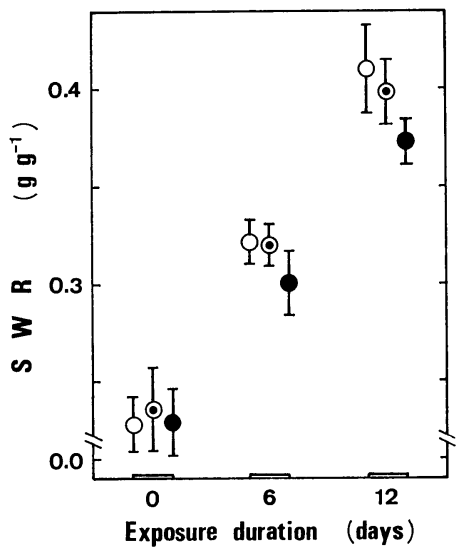

Fig. 8 Effect of $\mathrm{O}_{3}$ exposure on the stem weight ratio (SWR). Symbols and conditions are the same as in Fig. 1.

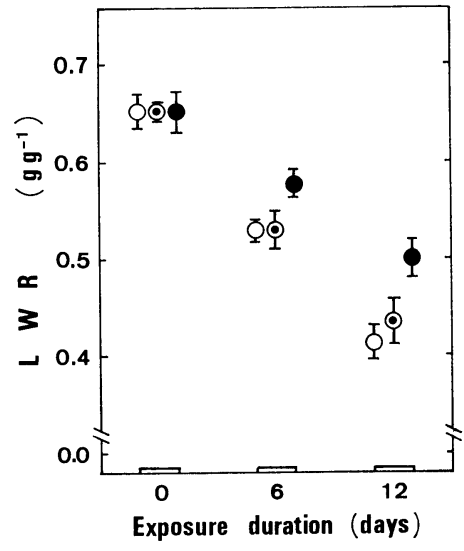

Fig. 7 Effect of $\mathrm{O}_{3}$ exposure on the leaf weight ratio (LWR). Symbols and conditions are the same as in Fig. 1.

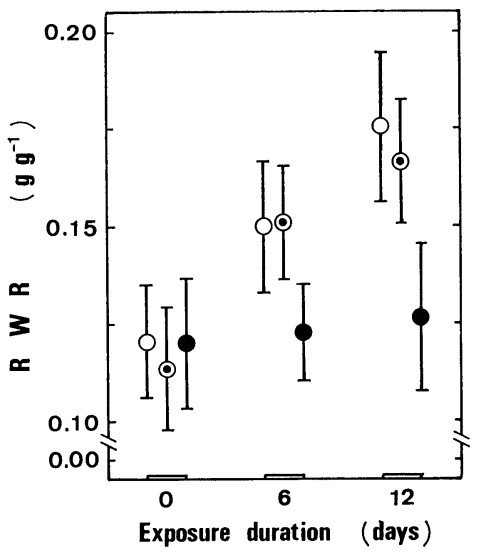

Fig. 9 Effect of $\mathrm{O}_{3}$ exposure on the root weight ratio (RWR). Symbols and conditions are the same as in Fig. 1 .

$\mathrm{O}_{3}$ increased LWR by $21 \%$ of the control value, while $0.1 \mathrm{ppm} \mathrm{O}_{3}$ increased $\mathrm{LWR}$ by $5 \%(P<0.05)$. We also calculated the ratio of dry weight of stem or root to that of whole plant (Figs. 8 and 9). The exposure to $0.1 \mathrm{ppm}_{3}$ for 12 days only slightly reduced both SWR and RWR, whereas $0.2 \mathrm{ppm} \mathrm{O}_{3}$ significantly reduced SWR and RWR by $9 \%$ and $28 \%$, respectively.

\section{DISCUSSION}

Dry matter production in sunflower plants was significantly reduced by the exposure to both 0.1 and $0.2 \mathrm{ppm} \mathrm{O}_{3}$ for 12 days (Fig. 1). These findings support the 
previously reported results that the chronic exposures to low concentrations of $\mathrm{O}_{3}$ inhibited plant growth and yield. ${ }^{16-24)}$ In addition, results of growth analysis in the present investigation suggested that several physiological functions participating in the plant growth were altered by $\mathrm{O}_{3}$ through the course of exposure period. The reduction in RGR caused by $\mathrm{O}_{3}$ exposure appeared to be derived from the effect of $\mathrm{O}_{3}$ on NAR. It has been well documented that the exposures to high concentrations of $\mathrm{O}_{3}$ inhibit the net photosynthesis and stimulate the respiration in several plants. ${ }^{10-12,14,15)}$ The reduction in NAR represented in the present study suggests that chronic exposures to low concentration of $\mathrm{O}_{3}$ could also induce the inhibition of net photosynthesis and/or the acceleration of respiration in plants. The reduction in NAR by exposure to $0.09 \mathrm{ppm} \mathrm{O}_{3}$ has been reported with other herbaceous plant species. $^{29)}$

However, for the last-half period of $0.1 \mathrm{ppm} \mathrm{O}_{3}$ exposure in the present experiments, the NAR was recovered or rather accelerated in the similar manner to the change in RGR. A similar result was reported by OsHrma et al. ${ }^{30)}$ who observed the reduction in RGR of the parsley plants caused by the exposure to $0.2 \mathrm{ppm} \mathrm{O}_{3}$ for the first several weeks, followed by the higher RGR than that of control plants. Such changes in NAR and RGR might be at least partly responsible for the stimulative effects of $\mathrm{O}_{3}$ on plant growth reported by several workers. ${ }^{25,26)}$ During the exposure to $\mathrm{O}_{3}$, plants might have adapted to the given environmental condition. Although the mechanisms of $\mathrm{O}_{3}$ phytotoxicity have not yet been defined, there were some studies that $\mathrm{O}_{3}$ in high concentrations could affect the activities of several enzymes. $^{31,32)}$ TANAKA and Sugahara ${ }^{33)}$ reported that poplar plants exposed to 0.1 ppm $\mathrm{SO}_{2}$ increased in superoxide dismutase activity and thereby became tolerant to acute toxicity of $\mathrm{SO}_{2}$. In the plants adapted to low concentrations of $\mathrm{O}_{3}$, the enzymes which participate in the defense of $\mathrm{O}_{3}$ toxicity might be also induced or activated during the exposure period. Studies on the enzymes relating to $\mathrm{O}_{3}$ tolerance should be prerequisite to know the mechanisms of adaptation to $\mathrm{O}_{3}$.

Plants exposed to $0.2 \mathrm{ppm} \mathrm{O}_{3}$ exhibited the smaller reduction in $\mathrm{RGR}$ than that in NAR for the last-half of exposure period (Table 2). The remarkable reduction in NAR induced by $\mathrm{O}_{3}$ could be compensated by the increase in LAR (Fig. 6) resulting in smaller reduction in RGR. The increase in LWR and the reduction in SWR and RWR caused by $\mathrm{O}_{3}$ indicated that low levels of $\mathrm{O}_{3}$ had changed the partitioning ratio of photosynthate among leaves, stem and root (Figs. 7, 8 and 9). BENNETT and Oshima ${ }^{34}$ observed the reduction in RWR of the carrot plants by a longterm exposure to $\mathrm{O}_{3}$. Other investigators have demonstrated that $\mathrm{O}_{3}$ could reduce the dry weight growth of root most severely, resulting in a reduction in RWR in plants. ${ }^{18,23,24,29,30)}$ It has been reported that the plants in deficiency of photosynthate showed larger reduction in dry weight growth of root than that of shoot. ${ }^{35}$ ) The reduction in $\mathrm{RWR}$ in $\mathrm{O}_{3}$-exposed plants might also result from the deficiency of photosynthate caused by $\mathrm{O}_{3}$. Another report indicated that $\mathrm{O}_{3}$ reduced the proportion of dry weight of fruits to that of whole plant. ${ }^{36)}$ Besides, present experiments also showed the reduction in dry weight growth of flower bud caused by $\mathrm{O}_{3}$ exposure (Table 1). These results suggest the changes in partitioning ratio of photosynthate in $\mathrm{O}_{3}$-exposed plants. The change in the partitioning ratio was probably caused by the inhibition of translocation of photosynthate or by the enhancement of respiration in the dissimilation parts, i.e. root, stem and flower. Recently, TINGEY et $a l .{ }^{37)}$ have suggested the inhibitory effect of $\mathrm{O}_{3}$ on translocation of photosynthate 
in ponderosa pine. Accordingly, the increase in total number of leaves and the acceleration of senescence of old leaves in $\mathrm{O}_{3}$-exposed plants (Table 1) should be further investigated in view of the changes in partitioning and translocation of photosynthate and other metabolites.

Retardation of stem elongation in $\mathrm{O}_{3}$-exposed plants might be resulted from the reduction in dry weight growth of stem. On the other hand, ethylene production was reported in plants exposed to high concentrations of $\mathrm{O}_{3}{ }^{38,39}$ ) It is known that ethylene inhibits stem elongation ${ }^{40)}$ and accelerates senescence. ${ }^{41)}$ By exposure to low concentrations of $\mathrm{O}_{3}$, plants might produce ethylene. Therefore, it is probable that retardation of stem elongation and acceleration of senescence caused by $\mathrm{O}_{3}$ exposure in the present experiment can be explained by ethylene production.

SHImizU et al. ${ }^{42)}$ investigated the effects of a long-term exposure to low concentrations of $\mathrm{SO}_{2}$ on the growth of sunflower plants. They found that $\mathrm{SO}_{2}$ altered the several growth parameters, which suggested some changes in physiological functions in plants. The method of growth analysis seems to be useful to analyze the changes in physiological functions resulting in the changes in growth and yield of plants exposed to an air pollutant and probably to pollutant mixture. However, in order to understand the precise mechanisms of the growth reduction of plants induced by chronic exposures to low concentrations of $\mathrm{O}_{3}$ and the mechanisms of adaptation of these plants, more direct studies on the effects on physiological phenomena, such as photosynthesis, respiration, enzyme activity, translocation of photosynthate and hormonal balance must be studied. Studies on some of these problems are in progress in our laboratory.

We are grateful to the members of the division of engineering of our institute, who helped maintain the environmental conditions of the growth cabinets and advised for cultivation of the plant materials. We are indebted to Dr. N. Kondo for helpful advice and discussion during the course of the present study and the preparation of this manuscript. We are also indebted to Dr. O. Ito for criticizing this paper.

\section{REFERENCES}

1) Heck, W. W. 1968. Factors influencing expression of oxidant damage to plants. Ann. Rev. Phytopathol. 6: 165-188.

2) Middleton, J. T. 1961. Photochemical air pollution damage to plants. Ann. Rev. Plant Physiol. 12: 431-448.

3) Ting, I. P., and R. L. Heath. 1975. Responses of plants to air pollutant oxidants. Adv. Agron. 27: 89-121.

4) U. S. Environmental Protection Agency. 1978. Air quality criteria for ozone and other photochemical oxidants. EPA. 600/8-78-004. PB80-124753. NTIS, U.S. Department of Commerce, Springfield, Va.

5) Heggestad, H. E. 1969. Consideration of air quality standards for vegetation with respect to Ozone. J. Air Pollut. Control Assoc. 19: 424-426.

6) Hill, A. C., H. E. Heggestad, and S. N. Linzon. 1970. Ozone. In "Recognition of Air Pollution Injury to Vegetation: A Pictorial Atlas." (Ed. by Jacobson, J. S., and A. C. Hill) B1B32, Air Pollut. Control Assoc., Pittsburgh.

7) Dunning, J. A., and W. W. Heck. 1977. Response of bean and tobacco to ozone: Effect of light intensity, temperature and relative humidity. J. Air Pollut. Control Assoc. 27: 882886.

8) Heggestad, H. E., and J. T. Middleton. 1959. Ozone in high concentrations as cause of tobacco leaf injury. Science 129: 208-300. 
9) Ting, I. P., and W. M. Dugger, Jr. 1968. Factors affecting ozone sensitivity and susceptibility of cotton plants. J. Air Pollut. Control Assoc. 18: 810-813.

10) Furukawa, A., and M. Kadota. 1975. Effect of ozone on photosynthesis and respiration in poplar leaves. Environ. Control in Biol. 13: 1-7.

11) Macdowall, F. D. H. 1965. Stages of ozone damage to respiration of tobacco leaves. Can. J. Bot. 43: 419-427.

12) Pell, E. J., and E. Brennan. 1973. Changes in respiration, photosynthesis, adenosine 5'-triphosphate, and total adenylate content of ozonated pinto bean foliage as they related to symptom expression. Plant Physiol. 51: 378-381.

13) Taniyama, T., K. Yamashita, and T. KoIke. 1976. Studies on the mechanism of injurious effects of toxic gases on crop plants. XIII. Effects of ozone in the air on the apparent photosynthesis of corn, rice and peanut plants. Proc. Crop Sci. Soc. Jpn. 45: 9-16 (In Japanese with English summary).

14) Todd, G. W. 1958. Effect of ozone and ozonated 1-hexene on respiration and photosynthesis of leaves. Plant Physiol. 33 : 416-420.

15) Todd, G. W., and B. Propst. 1963. Changes in transpiration and photosynthetic rates of various leaves during treatment with ozonated hexene or ozone gas. Physiol. Plant. 16: 5765.

16) Feder, W. A. 1970. Plant response to chronic exposure of low levels of oxidant type air pollution. Environ. Pollut. 1: 73-79.

17) Heagle, A. S., D. E. Body, and E. K. Pounds. 1972. Effect of ozone on yield of sweet corn. Phytopathology 62: 683-687.

18) Tingey, D. T., R. A. Reinert, C. Wickliff, and W. W. Heck. 1973. Chronic ozone or sulfur dioxide exposures, or both, affect the early vegetative growth of soybean. Can. J. Plant Sci. 53: 875-879.

19) Heagle, A. S., S. Spencer, and M. B. Letchworth. 1979. Yield response of winter wheat to chronic doses of ozone. Can. J. Bot. 57: 1977-2005.

20) Jensen, K. F., and L. S. Dochinger. 1974. Responses of hybrid poplar cuttings to chronic and acute levels of ozone. Environ. Pollut. 6: 289-295.

21) Manning, W. J., W. A. Feder, P. M. Papia, and I. Perkins. 1971. Influence of foliar ozone injury on root development and root surface fungi of pinto bean plants. Environ. Pollut. 1: $305-312$.

22) Oshima, R. J., O. C. Taylor, P. K. Braegelmann, and D. W. Baldwin. 1975. Effect of ozone on the yield and plant biomass of a commercial variety of tomato. J. Environ. Qual. 4: 463-464.

23) Tingey, D. T., W. W. Heck, and R. A. Reinert. 1971. Effect of low concentrations of ozone and sulfur dioxide on foliage, growth and yield of radish. Am. Soc. Hortic. Sci. 96: $369-371$.

24) Tingey, D. T., and R. A. Reinert. 1975. The effect of ozone and sulphur dioxide singly and in combination of plant growth. Environ. Pollut. 9: 117-125.

25) Harward, M., and M. Treshow. 1975. Impact of ozone on the growth and reproduction of understorey plants in the aspen zone of western U.S.A. Environ. Conserv. 2: 17-23.

26) Bennett, J. P., H. M. Resh, and V. C. Runeckles. 1973. Apparent stimulations of plant growth by air pollutants. Can. J. Bot. 52: 35-41.

27) Hewitt, E. J. 1966. "Sand and Water Culture Methods Used in the Study of Plant Nutrition." Common. Agric. Bur., Farnham Royal, Bucks, England.

28) Evans, G. C. 1972. "The Quantitative Analysis of Plant Growth." William Clowes and Sons Ltd., London.

29) Horsman, D. C., A. O. Nicholls, and D. M. Calder. 1980. Growth responses of Dactylis glomerata, Lolium perenne and Phalaris aquatica to chronic ozone exposure. Aust. J. Plant Physiol. 7: 511-517.

30) Oshima R. J., J. P. Bennett, and P. K. Braegelmann. 1978. Effects of ozone on growth and assimilate partitioning in parsley. J. Am. Soc. Hortic. Sci. 103: 348-350. 
31) Dass, H. C., and G. M. Weaver. 1972. Enzymatic changes in intact leaves of Phaseolus vulgaris following ozone fumigation. Atmos. Environ. 6: 759-763.

32) Tingey, D. T., R. C. Fites, and C. Wickliff. 1976. Differential foliar sensitivity of soybean cultivars to ozone associated with differential enzyme activities. Physiol. Plant. 37: 69-72.

33) Tanaka, K., and K. Sugahara. 1980. Role of superoxide dismutase in defense against $\mathrm{SO}_{2}$ toxicity and an increase in superoxide dismutase activity with $\mathrm{SO}_{2}$ fumigation. Plant Cell Physiol. 21: 601-611.

34) Bennett, J. P., and R. J. Oshima. 1976. Carrot injury and yield response to ozone. J. Am. Soc. Hortic. Sci. 101 : 638-639.

35) Curtis, O. F., and D. G. Clark. 1950. "An introduction to plant physiology." McGraw-Hill Book Co. Inc., New York.

36) Bennett, J. P., R. J. Oshima, and L. F. Lippert. 1979. Effects of ozone on injury and dry matter partitioning in pepper plants. Environ. Exp. Bot. 19: 33-39.

37) Tingey, D. T., R. G. Wilhour, and C. Standley. 1976. The effect of chronic ozone exposures on the metabolite content of ponderosa pine seedlings. For. Sci. 22: 234-241.

38) Craker, L. E. 1971. Ethylene production from ozone injured plants. Environ. Pollut. 1: 299-304.

39) Tingey, D. T., C. Standley, and R. W. Field. 1976. Stress ethylene evolution: A measure of ozone effects on plants. Atmos. Environ. 10: 969-974.

40) Burg, S. P., and E. A. Burg. 1966. The interaction between auxin and ethylene and its role in plant growth. Proc. Natl. Acad. Sci. 55: 262-266.

41) Burg, S. P. 1968. Ethylene, plant senescence, and abscission. Plant Physiol. 43: 1503-1511.

42) Shimizu, H., A. Furukawa, and T. Totsuka. 1980. Effects of low concentrations of $\mathrm{SO}_{2}$ on the growth of sunflower plants. Environ. Control in Biol. 18: 39-47.

$<$ 和文抄録 $>$

\title{
ヒマワリの生長に及ばすオン゙ン長期暴露の影響
}

\author{
清水英幸*·本橋 理** ·岩城英夫**·古川昭雄*·戸塚 績* \\ * 国立公害研究所生物環境部 \\ ** 筑波大学生物科学系
}

一定の環境に制御した人工光型グロースキャビネットで，ロシアヒマワリを播種後 14 日めから 12 日 間, $0.1 \mathrm{ppm}$ および $0.2 \mathrm{ppm}$ のオゾン $\left(\mathrm{O}_{3}\right)$ に暴露し, 植物の乾物生長に及ぼす $\mathrm{O}_{3}$ の影響について検 討した. $\mathrm{O}_{3}$ 暴露開始日および 6 日め, 12 日めに植物を選出して葉面積, 器官別乾重などを測定し, そ

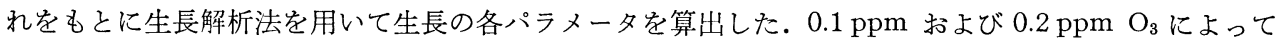

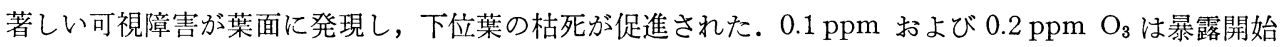
後 12 日めで, 植物個体の乾重をおのおの対照より $11 \%, 32 \%$ 減少させた. $\mathrm{O}_{3}$ 暴露によって各器官と も乾重の増加が抑制されたが, その程度は根で最も大きく, 葉で最も小さかった。 また葉面積増加も葉 乾重増加と同程度に $\mathrm{O}_{3}$ によって抑制された. 生長解析の結果, $0.1 \mathrm{ppm} \mathrm{\textrm {O } _ { 3 }}$ は暴露前半の 6 日間に植物 の相対生長率(RGR) や純同化率(NAR) を対照と比較して減少させたが，後半は減少させなかった。こ れに対して $0.2 \mathrm{ppm} \mathrm{O}_{3}$ は暴露期間を通じ RGR や NAR を減少させたが, 後半における RGRの減少 率は NAR の減少率に比べて小さかった. また $0.2 \mathrm{ppm} \mathrm{O}$ は植物の葉面積比(LAR)や葉重比(LWR) を対照より増加させたが, 一方茎重比 (SWR) や根重比 (RWR) を減少させた. これらの結果から, 低 濃度 $\mathrm{O}_{3}$ の長期間暴露は植物の純光合成速度や光合成産物の分配率に影響することが示唆された。 